\title{
Pengaruh Uses And Gratification terhadap Adiksi Instagram pada Emerging Adulthood di Kota Bandung
}

\author{
Naflah Adela Adristiyani *, Lilim Halimah \\ Prodi Psikologi, Fakultas Psikologi, Universitas Islam Bandung, Indonesia. \\ *adelaadrst@gmail.com, lilimbintiumar@gmail.com
}

\begin{abstract}
The results of the latest study show an increase in the duration of social media use in Indonesia during the pandemic. Instagram since 2017 has been the worst SNS that impact for mental health. Instagram users in Indonesia are dominated by 18-24 year olds who belong to Generation Z or called iGen, so they are more susceptible to addiction. One of the predictors of Instagram addiction is uses and gratification. This study aims to examine the effect of uses and gratification on instagram addiction in emerging adulthood in Bandung. The analysis technique used is multiple regression. Subjects were 230 people who were selected using convenience sampling. The measuring tools are Instagram use motivations and The Instagram Addiction Scale (TIAS). The results showed that uses and gratifications had an effect on Instagram addiction based on the significance value is $0.000<0.05$, with an effect of $21.3 \%$. Recognition and Entertainment are have an effect on instagram addiction, while Information and Social have no effect. Recognition has an effect of $10.69 \%$ on instagram feed addiction and entertainment has an effect of $9.39 \%$ on instagram stories addiction.
\end{abstract}

Keywords: instagram addiction, uses and gratification, social media

Abstrak. Hasil studi terbaru menunjukkan terjadinya peningkatan durasi pengunaan media sosial di Indonesia selama pandemi. Instagram sejak tahun 2017 merupakan SNS yang memiliki pengaruh paling buruk bagi kesehatan mental dan penggunanya Pengguna instagram di Indonesia didominasi usia 18-24 tahun yang termasuk ke dalam Generasi Z(iGen) sehingga lebih rentan terkena adiksi. Salah satu faktor prediktor terjadinya adiksi instagram adalah uses and gratification. Penelitian ini bertujuan melihat pengaruh uses and gratification terhadap adiksi instagram pada emerging adulthood di Kota Bandung. Teknik analisis yang digunakan adalah analisis uji regresi linier berganda. Subjek berjumlah 230 orang yang dipilih menggunakan convenience sampling. Alat ukur yang digunakan adalah instagram use motivations dan The Instagram Addiction Scale (TIAS). Hasil penelitian menunjukkan bahwa uses and gratification berpengaruh terhadap adiksi instagram dilihat berdasarkan nilai signifikansinya yaitu $0,000<0,05$, dengan pengaruh sebesar 21,3\%. Recognition dan Entertainment berpengaruh terhadap adiksi instagram sedangkan Information dan Social tidak berpengaruh. Recognition berpengaruh 10,69\% terhadap adiksi instagram feed dan Entertaiment berpengaruh 9,39\% terhadap adiksi instagram stories.

Kata Kunci: adiksi instagram, uses and gratification, media sosial. 


\section{A. Pendahuluan}

Pada era revolusi 4.0 saat ini segala sesuatu erat kaitannya dengan internet dan segala aktivitas pun dapat dilakukan secara mudah dengan hadirnya internet. Hasil studi terbaru menunjukkan terjadinya peningkatan durasi pengunaan internet selama pandemi COVID-19 dengan rata-rata peningkatan 3,43 jam per hari jika dibandingkan sebelum pandemi COVID-19 dan media sosial menjadi salah satu motif utama yang berkontribusi terjadinya peningkatan tersebut (Siste et al., 2020). Hasil survey yang dilakukan oleh Asosiasi Penyelenggara Jasa Internet Indonesia (APJII) pada tahun 2019-2020 didapatkan bahwa sebanyak 51,5\% alasan utama penggunaan internet di Indonesia adalah untuk media sosial dan alasan kedua adalah untuk berkomunikasi lewat pesan (APJII,2020).

Selama dekade terakhir, penggunaan media sosial dan banyak subformasinya termasuk penggunaan social networking telah berkembang pesat dan SNS telah menjadi media integral untuk berkomunikasi dalam hubungan interpersonal yang pada akhirnya juga mengakibatkan penggunaan bermasalah pada sebagian penggunya salah satunya adalah terjadinya adiksi (Kuss \& Griffiths, 2011;2017; Fox, Jesse \& Jennifer J. Moreland,2015).

Adiksi dilihat dari biopsychosocial framework merupakan perilaku yang dapat terjadi karena interaksi berbagai macam faktor termasuk kecenderungan biologis atau genetik, psikologis (misalnya faktor kepribadian, motivasi bawah sadar, attitude, harapan dan belief) dan lingkungan sosial (Griffiths, 2005).

Adiksi SNS merupakan perilaku kecanduan dengan gejala seperti; mengutamakan ketertarikan untuk menggunakan SNS (salience), terdapat kondisi penggunaan SNS dapat mengubah mood pengguna (mood modification), menurunkan toleransi terhadap penggunaan SNS (tolerance), munculnya perilaku penarikan diri saat menggunakan SNS (withdrawal), kambuhnya kecanduan SNS (relapse) dan munculnya konflik dengan lingkungan sekitar terkait dengan penggunaan situs jejaring sosial (conflict). (Kuss \& Griffiths, 2017).

Konsekuensi negatif yang ditimbulkan akibat adiksi SNS diantaranya penurunan akademis, menuruannya life satisfaction, shyness, gangguan kesehatan, serta masalah privasi dan keamanan, gangguan pada hubungan soisal, kenakalan yang meningkat, tekanan finansial, dan kecemasan. (Abdulahi et al. 2014; Ponnusamy et al. 2020; Stockdale \& Coyne, 2020).

Penelitian-penelitian terbaru menunjukkan individu dapat mengembangkan masalah terkait adiksi sebagai konsekuensi dari penggunaan SNS salah satunya adalah Instagram (Kuss \& Griffith,2017). Literatur terkait adiksi instagram masih dalam tahap awal dan masih banyak pertanyaan penelitian terbuka mengenai faktor-faktor yang terkait dengan adiksi instagram (Kuss \& Griffiths, 2017; Ponnusamy et al. 2020).

Dalam beberapa tahun terakhir, ahli kesehatan telah memperingatkan dampak negatif terhadap penggunaan berlebihan pada platform berbasis foto salah satunya instagram (Wiederhold, 2019). Berdasarkan laporan Royal Society for Public Health (2017) didapatkan bahwa platform instagram merupakan media sosial yang paling buruk untuk kesehatan mental, didapatkan hasil bahwa instagram dapat mempengaruhi tingkat kecemasan dan ketidakpuasan tubuh, meminbulkan perasaan tidak mampu dan penurunan well-being serta fear of missing out dan dapat menimbulkan pengalaman negatif.

Instagram memang memiliki kekhususan di bidang visual dan merupakan aplikasi yang memberikan layanan komunikasi dengan konsep gambar dan dapat digunakan secara mudah sehingga lebih banyak digemari (Atmoko, 2012; Sheldon \& Bryant, 2016). Instagram merupakan platform paling popular kedua di Indonesia setelah facebook dan saat ini pengguna instagram di Indonesia berjumlah 88.220.00, jumlah ini terus meningkat setiap tahunnya. (Hootsuite \& We Are Social,2020; NapoleonCat.com, 2021).

Pengguna instagram di Indonesia didominasi pada rentang usia 18-24 tahun (Hootsuite \& We Are Social 2020; NapoleonCat.com 2021). Usia tersebut termasuk ke dalam rentang usia emerging adulthood dan sesuai dengan kategorisasi dari The Center For Generational Kinetics (2016) termasuk ke dalam generasi Z (iGen) yang dinyatakan bahwa sebagian besar anggota generasi $\mathrm{Z}$ (iGen) sering lupa waktu ketika menggunakan media sosial dan cenderung menjalani sebagian besar hidup mereka secara online dan melalui smartphone. Generasi yang lebih memiliki resiko yang lebih tinggi untuk mengembangkan gejala adiksi SNS dan individu 
yang lebih muda cenderung menganggap penggunaan SNS mereka tidak terlalu bermasalah daripada orang tua mereka (Valkenburg \& Peter 2011; Kuss \& Griffiths, 2017).

Adiksi disebabkan oleh interaksi berbagai faktor biopsikososial. Uses and Gratification merupakan salah satu faktor psikologis yang berkaitan dengan adiksi Instagram, Uses and Gratifcation merupakan motif penggunaan media berdasarkan psychological need dan social need yang akan meprediksi gratifikasi/kepuasan yang didapatkan pada media tertentu (Katz et al. 1973). Motif individu untuk menggunakan SNS dapat menjadi faktor yang menjadi masalah (Kuss dan Griffiths 2011, 2017).

Individu berperan aktif dalam penggunaan media karena terlibat dengan media memungkinkan mereka untuk memuaskan kebutuhan psikologis dan sosial mereka (Katz et al. 1973; Tan, 1985; Wu, Wang, \& Tsai, 2010). Uses and gratification setiap individu akan berbeda tergantung dengan SNS yang digunakan didasari kebutuhan dan kepuasan yang diperoleh (Gülnar, Balcé \& Çakér, 2010; Mull \& Lee, 2014; Alhabash \& Ma (2017). Pengguna instagram diasumsikan mengalami kepuasan melalui berbagi foto dan motivasi untuk berbagi foto dapat dijelaskan dengan teori uses and gratification (Kuss \& Griffiths,2017).

Penelitian terkait pengaruh uses and gratification terhadap adiksi instagram di Indonesia masih sangat terbatas terutama yang melihat secara spesifik kedua fitur utama instagram yaitu feed dan stories. Smock et al. (2011) mengidentifikasi bahwa ketika membagi penggunaan umum media sosial ke dalam fitur yang berbeda, maka akan didapatkan penjelasan yang lebih rinci tentang bagaimana motif terkait dengan penggunaannya dan dalam beberapa kasus juga menunjukkan hubungan positif dan negatif yang berbeda ketika hanya melihat penggunaan secara umum. Sehingga ketika uses and gratification diketahui secara lebih spesifik pada fitur feed dan stories maka akan diperoleh informasi yang lebih jelas mengenai alasan seseorang menggunakan media sosial dan pengaruhnya terhadap adiksi instagram. Dengan diketahuinya uses and gratification yang merupakan faktor psikologis yang dapat menjadi salah stau prediktor terhadap terjadinya adiksi instagram diharapkan penelitian ini dapat menjadi sumber tambahan dalam upaya pengurangan dampak negatif dari penggunaan instagram khususnya di Indonesia.

Berdasarkan pemaparan tersebut maka tujuan dari penelitian ini adalah :

1. Mengetahui gambaran kontribusi uses and gratification terhadap adiksi instagram pada emerging adulthood di Kota Bandung

2. Untuk meneliti pengaruh empat kategori uses and gratification instagram yaitu recognition, social, information dan entertainment terhadap adiksi instagram pada emerging adulthood di Kota Bandung

3. Untuk meneliti kategori uses and gratification yang paling berpengaruh terhadap adiksi instagram pada emerging adulthood di Kota Bandung

4. Untuk meneliti kategori uses and gratification yang paling berpengaruh terhadap adiksi instagram secara spesifik pada fitur utamanya yaitu feed dan stories

\section{B. Metodologi Penelitian}

Variabel independen pada penelitian ini adalah uses and gratification (X) dan Variabel dependen pada penelitian ini adalah adiksi instagram (Y). Sampel yang digunakan pada penelitian ini adalah emerging adulthood di Kota Bandung yang berusia 18-24 tahun, memiliki akun instagram dan aktif mengggunakannya selama 1 tahun terakhir dan terindikasi mengalami adiksi instagram. Subjek berjumlah 230 orang yang dipilih menggunakan convenience sampling. Pengumpulan data dilakukan secara daring melalui google form dengan menggunakan alat ukur instagram use motivations oleh Ponnusamy et al. (2020) yang telah diadaptasi ke dalam Bahasa Indonesia oleh peneliti dan The Instagram Addiction Scale (TIAS) oleh Sholeh, A., \& Rusdi, A. (2019). Desain penelitian yang digunakan adalah kausalitas dengan metode kuantitatif. Teknik analisis yang digunakan adalah analisis uji regresi linier berganda (multiple regression) yang terdiri dari uji f, uji t dan koefisien determinasi. 


\section{Hasil dan Pembahasan}

Pada penelitian ini, uji regresi linier berganda dilakukan dengan menggunakan software SPSS versi 23. Dalam menginterpretasi hasil analisis regresi linier berganda maka perlu dilakukan uji $\mathrm{F}$, uji t, koefisien determinasi dan melihat kontribusi pengaruh yang diberikan variabel independen $(\mathrm{X})$ terhadap variabel dependen $(\mathrm{Y})$.

Tabel 3. Hasil Uji Statistik

\begin{tabular}{|c|c|c|c|c|}
\hline $\begin{array}{l}\text { Hasil } \\
\text { Uji }\end{array}$ & & Sig. & $\begin{array}{l}\text { Koefisien } \\
\text { Determinasi } \\
\left(\mathrm{R}^{2)}\right.\end{array}$ & $\%$ \\
\hline Uji F & $\begin{array}{l}\text { Uses and } \\
\text { gratification }\end{array}$ & 0.000 & 0.213 & $21,3 \%$ \\
\hline \multirow{4}{*}{ Uji t } & Recognition & 0.001 & & $9,29 \%$ \\
\hline & Social & 0.210 & & $3,22 \%$ \\
\hline & Information & 0.006 & & $-2,05 \%$ \\
\hline & Entertaiment & 0.000 & & $10,86 \%$ \\
\hline
\end{tabular}

Tabel 2. Hasil Pengaruh Parsial Kategori Uses and Gratification terhadap Adiksi Instagram Feed dan Stories

\begin{tabular}{|c|c|c|}
\hline & $\begin{array}{l}\text { Total Pengaruh terhadap Adiksi } \\
\text { Instagram Feed }\end{array}$ & $\begin{array}{l}\text { Total Pengaruh terhadap Adiksi } \\
\text { Instagram Stories }\end{array}$ \\
\hline Recognition & $10.69 \%$ & $6.03 \%$ \\
\hline Social & $2.02 \%$ & $3.67 \%$ \\
\hline Information & $-1.80 \%$ & $-1.79 \%$ \\
\hline Entertaiment & $9.81 \%$ & $9.39 \%$ \\
\hline Total & $20,7 \%$ & $17,3 \%$ \\
\hline
\end{tabular}

Berdasarkan nilai sginifikansi pada hasil uji $\mathrm{F}$ (lihat tabel 3.1) didapatkan bahwa nilai signifikansi adalah 0,00 sehingga tidak lebih dari 0,05 dan dapat diartikan bahwa hipotesis 1 pada penelitian terbukti yaitu uses and gratification berpengaruh terhadap adiksi instagram. Uses and Gratification berpengaruh sebesar $21,3 \%$ beradasarkan nilai $\mathrm{R}^{2}$ yaitu 0,213 yang terdapat di tabel 3.1. Sejalan dengan hasil penelitian sebelumnya yang menyatakan bahwa uses and gratification menjadi salah satu faktor yang dapat mempengaruhi terjadinya adiksi pada seseorang (Kuss \& Griffiths, 2017; Hwang and Cho,2018; Ponnusamy et al.2020). Sesuai dengan teori yang dikemukakan oleh Katz et al. (1973) bahwa individu secara aktif mencari dan memenetukan media tertentu untuk mendapatkan kepuasan dari padanya. Ketika seseorang memiliki motif tertentu dalam menggunakan instagram (uses) dengan tujuan untuk mendapatkan kepuasan daripadanya (gratification), maka akan semakin sering instagram digunakan, pada akhirnya hal tersebut dapat menyebabkan seseorang menjadi adiksi. Sejalan dengan konsep adiksi bahwa inividu menjadi adiksi diawali dengan didaapatkannya kepuasan atau kesenangan tertentu sehingga yang akhirnya menyebabkan ketergantungan secara psikologis antara inividu dengan hal tersebut, pada penelitian ini maka instagram yang dijadikan media untuk memenuhi kebutuhan individu.

Pengaruh uses and gratification tetrhadap adiksi instagram sebesar $21,3 \%$ sedangkan sisanya dipengaruhi oleh faktor lain yang tidak diteliti pada penelitian ini. Hasil ini sejalan dengan teori yang disampaikan oleh Griffiths (2005) bahwa adiksi merupakan perilaku yang dapat terjadi akibat gabungan dari berbagai macam faktor. Dalam penelitian ini uses and gratification merupakan faktor psikologis yang didasari oleh psychological needs dan social needs. Ketika menggunakan instagram individu mendapatkan kepuasan dengan mengunggah JRP is licensed under Creative Commons Atribution- 
foto/video di instagram dan membagikannya ke orang lain (Kuss \& Griffiths, 2017).

Uses and gratification ditentukan berdasarkan psychological needs dan social needs setiap individu, maka akan terdapat jenis uses and gratification yang berbeda dari setiap inividu tergantung karakteristik dan juga media yang digunakannya (Katz et al, 1973; Tan, 1985). Seiring dengan perkembangan teknoloogi di dunia media pun turut berkembang, dan saat ini media yang digunakan berkaitan dengan internet. Setiap media memiliki fitur tersendiri dan individu pun secara sadar memilih media tertentu sesuai dengan kebutuhan yang ingin didapatkan. Pada penelitian ini uses and gratification yang diteliti pengaruhnya terhadap instagram terdiri dari 4 jenis kategori yaitu recognition needs, social needs, information needs dan entertainment needs, kategori ini didapatkan berdasarkan dari hasil penelitian-penelitian sebelumnya (Whiting \& William, 2013; Sheldon \& Bryant, 2016; Alhabash \& Ma, 2017; Ponnusamy et al.2020).

Pengaruh setiap kategori uses and gratification terhadap adiksi instagram dapat dilihat pada hasil uji t (lihat tabel 3.1). Berdasarkan nilai signifikansi dari setiap kategori, didaptkan recognition needs memiliki nilai signifikansi 0,001 , social needs bernilai 0,210 , information needs bernilai 0,06 dan entertainment needs bernilai 0,000. Dari nilai signifikansi tersebut dapat diartikan bahwa recognition dan entertainment memiliki pengaruh terhadap adiksi instagram karena memiliki nilai signifikansi tidak lebih dari 0,05. Sedangkan untuk social dan information tidak memiliki pengaruh terhadap adiksi instagram karena nilai siginifikansinya bernilai lebih dari 0,05 .

Hasil ini berbeda dengan penelitian sebelumnya yang dilakukan oleh Ponnusamy et al. (2020) yang menyatakan bahwa recognition needs dan social needs merupakan kategori yang paling berpengaruh terhadap adiksi instagram dan information needs serta entertainment needs tidak berpengaruh secara signifikan terhadap adiksi instagram. Hasil ini sejalan dengan penelitian Stockdale \& Coyne (2020) yang menyatakan bahwa entertainment needs berpengaruh secara langsung dengan adiksi SNS. Pada penelitian sebelumnya juga ditemukan bahwa diversion dan self presentation berpengaruh terhadap adiksi instagram (Krishnan \& Hunt, 2015; Sheldon \& Bryant, 2016).

Self presentation merupakan bagian dari recognition needs, kebutuhan ini adalah kebutuhan untuk merasa diakui oleh orang lain dengan menunjukkan identitas pribadinya kepada orang lain. Seperti yang tertera pada item-item pernyataan yang ada di penelitian ini, bahwa ketika menggunakan instagram inidividu membentuk identitas pribadinya, inidividu membangun kepercayaan dirinya, individu merasa dihormati dan mendapat dukungan serta individu mendapatkan kepuasan ketika dapat mempromosikan dan mempublikasikan keahliannya. Ketika individu merasa dihargai dan dihormati ketika memgunggah foto/video melalui instagram pada akhirnya akan membuat individu terus menerus menggunakan instagram untuk mendapatkan kepuasan.

Kategori uses and gratification selanjutnya yang berpengaruh adalah entertainment needs yang didasari untuk memenuhi kebutuhan individu agar merasakan kesenangan dan relaxation. Berdasarkan hasil penelitian sebelumnya ketika individu menggunakan instagram untuk diversion maka individu bertujuan mendapatkan kesenangan dan juga passing time adalah prediktor yang kuat dan berpengaruh pada peningkatan penggunaan instagram yang pada akhirnya akan menyebabkan perilaku adiksi instagram (Krishnan \& Hunt, 2015; Alhabash \& Ma,2017; Kircaburun et al.2020, Stockdale \& Coyne 2020). Maka ini sejalan dengan hasil penelitian ini bahwa entertainment needs yaitu kebutuhan untuk mendapatkan kesenangan dan hiburan berpengaruh terhadap adiksi instagram. Individu merasa terhibur ketika menggunakan instagram karena instagram bergerak di bidang visual sehingga pada akhirnya individu merasa senang karena dapat terhibur melalui video atau foto yang di unggah dan terpampang pada akun instagramnya.

Social needs pada penelirian ini ditemukan tidak memiliki pengaruh terhadap adiksi instagram. Social needs pada penelitian ini adalah ketika individu menggunakan instagram untuk mengungkapkan perasaan, berbagi pandangan, pemikiran, dan pengalaman serta untuk tetap berhubungan dengan orang lain. Sejalan dengan hasil penelitian sebelumnya bahwa pengguna instagram justru kurang menekankan pengguannya untuk social, walaupun memang 
benar instagram menjadi salah satu SNS yang dapat memfasiliatsi untuk dapat terhubung dengan orang lain.(Floros \& Giomos, 2013; Sheldon \& Bryant, 2016; Alhabash \& Ma, 2017). Hasil ini membuktikan bahwa pada akhirnya uses and gratification akan disesuaikan dengan kebutuhan dari masing-masing individu dan tergantung juga media yang dipakainya.

Information needs pada penelitian ini dinyatakan tidak berpengaruh terhadap adiksi instagram. Hasil ini sejalan dengan penelitian yang dilakukan oleh Ponuusamy et al.(2020) yang juga menyatakan bahwa information needs tidak memiliki pengaruh secara signifikan terhadap adiksi instagram. Walaupun pada penelitian sebelumnya dinyatakan bahwa idividu memang mendapatkan informasi baru melalui instagram dengan mengandalkan informasi dari orang lain (Krishnan \& Hunt, 2015) tetapi pada akhirnya hasil tersebut berbeda dengan penelitian ini.

Berdasarkan hasil uji statistik dengan menggunakan zero-order didapatkan juga persentase pengaruh dari setiap kategori uses and gratification terhadap adiksi instagram yang dapat dilihat pada tabel 3.1. Dari keempat kategori yang diteliti yaitu recognition needs, social needs, information needs dan entertainment needs didapatkan bahwa yang paling berpengaruh terhadap adiksi instagram adalah entertainment needs yaitu dengan total pengaruh sebesar $10,86 \%$ dan recognition needs berpengaruh sebesar 9,29\%. Ketika individu menggunakan instagram untuk mendpaatkan kesenangan dan menghilangkan kebosanan maka hal terebut pada akhirnya akan terkait langsung dengan pola bermasalah penggunaan instagram yang ditandai dengan kesulitan melepaskan diri dari instagram, pre-occupation dengan situs tersebut, dan gangguan pada hubungan sosial (Stockdale \& Coyne, 2020). Hal ini juga berkaitan dengan kriteria adiksi yaitu mood modification yakni ketika individu merasakan perubahan mood ketika menggunakan instagram dan mendapatkan kesenaganan daripadanya, serta sebagai bentuk diversion dari dirinya sehingga instagram menjadi salah satu ocoping stress bagi individu. Hingga akhirnya terjadi peningkatan penggunaan instagram atau pada kriteria adiksi adalah tolerance.

Recognition needs juga turut berkontribusi pada terjadinya adiksi instagram. Sheldon dan Bryant (2016) menemukan bahwa pengguna instagram justru memang lebih berfokus menunjukkan identitas pribadi dan self-promotion. Pembentukan identitas pribadi dan self promotion merupakan bentuk dari recognition needs yaitu adanya kebutuhan untuk diperhatikan, kebutuhan untuk menunjukkan keberadaan kita di depan orang lain. Kebutuhan tersebut dapat terpenuhi dengan memposting foto pada instagram feed. Hasil ini juga sejalan dengan penelitian yang dilakukan oleh Ponnusamy et al.(2020) yang menyatakan bahwa recognition needs menjadi salah satu kategori yang paling berpengaruh terhadap adiksi instagram. Pada penelitian sebelumnya dinyatakan bahwa salah satu kebutuhan psikologis yang dimiliki individu meliputi kebutuhan untuk merasa dilihat dan dihargai terutama pada masa emerging adulthood yang cenderung mengeksplorasi identitas diri dengan mencari persetujuan dari orang (Greenwood, 2013; Arnett, 2014). Kebutuhan tersebut pada akhirnya dapat terpenuhi dikarenakan adanya fitur like, comment pada instagram feed. Ini juga berkaitan dengan kriteria adiksi yaitu salience, yakni ketika individu merasa terus memikirkan instagram bahkan ketika tidak menggunakannya.

Penleitian ini juga menggali lebih dalam terkait dengan pengaruh uses and gratification terhadap adiksi instagram berdasarkan dua fitur utamanya yaitu instagram yaitu feed dan stories. Terdapat perbedaan jenis kategori yang paling berpengaruh terhadap adiksi instagram feed dan stories. Pengaruh uses and gratification terhadap adiksi instagram feed berdasarkan tabel 3.2 adalah 20,7\% dan kategori yang paling berpengaruh adalah recognition needs dengan pengaruh sebesar 10,69\%. Didapatkan juga bahwa pengaruh uses and gratification terhadap adiksi instagram stories adalah $17,3 \%$ entertainment needs adalah yang paling berpengaruh dengan persentase $9,39 \%$.

Perbedaan persentase setiap kaetgori uses and gratification yang paling berpengaruh antara adiksi instagram feed dan stories dapat disebabkan karena fitur dari keduanya yang berbeda. Sejalan dengan Smock et al. (2011) yang menyatakan bahwa ketika motif penggunaan (uses) dilihat secara lebih sepsifik pada fitur-fitur yang digunakannya maka akan didapatkan hasil yang lebih jelas dan rinci dibandingkan ketika hanya melihat secara general. 
Terbukti bahwa terdapat perbedaan uses and gratification yang paling beperngaruh antara kedua fitur instagram.

Instagram feed memfasilitasi pengguna instagram untuk mendapatkan feedback dari pengguna instagram lain berdasarkan likes dan comment yang ada pada postingan foto atau video yang diunggah. Sejalan dengan hasil penelitian yang dilakukan oleh Alahabash \& Ma (2017) bahwa pengguna instagram memang menekankan pada jumlah audience atau followers dalam menggunakan instagram dibandingkan platform lain. Sehingga fitur likes dan comment tersebut dilihat sebagai bentuk pemenuhan recognition needs atau kebutuhan akan pengakuan dari orang lain.

Sedangkan Instagram stories mengacu pada konsep digital storytelling yang memungkinkan pengguna untuk bercerita tentang kehidupan sehari-hari mereka dengan mengirimkan foto dan video yang hilang secara otomatis setelah 24 jam dan disajikan di seluruh layar selama 15 detik pada setiap foto atau video (Instagram, 2017;Kircaburun \& Griffiths,2018; Belanche et al. 2019). Setiap stories yang diunggah oleh seseorang akan diikuti oleh stories dari pengguna instagram yang lain, dan pengguna memiliki kontrol untuk melihat lagi stories sebelumnya dan berikutnya dalam urutan waktu. Dengan konsep yang ada pada stories tersebut maka memungkinkan individu mendapatkan kesenangan dan relaksasi ketika menoton instagram stories.

\section{Kesimpulan}

Berdasarkan hasil analisis data dan diskusi, maka dapat disimpulkan :

1. Uses and Gratification secara simultan berpengaruh signifikan terhadap adiksi instagram dengan pengaruh sebesar $21,3 \%$ sehingga uses and gratification dapat menjadi salah satu faktor prediktor terjadinya adiksi instagram.

2. Recognition needs berpengaruh secara signifikan terhadap adiksi instagram. Karena instagram memiliki kekhasan di bidang visual maka individu lebih terfokus kepada kepuasan yang mengarah pada self presentation. Ketika individu merasa diakui dengan mendapatkan like dan comment melalui instagram maka akan semakin membuat individu terus menerus menggunakan instagram untuk mendapatkan kepuasan tersebut sehingga dapat mengarah pada terjadinya adiksi.

3. Social needs dan Information needs tidak memiliki pengaruh secara siginifikan terhadap adiksi instagram hal ini

4. Entertaiment needs berpengaruh secara siginifkan terhadap adiksi instagram dan merupakan kategori yang paling berpengaruh dibandingkan keempat kategori lainnya. Ketika individu mengelola kebosanan dan mendapatkan kesenangan sehingga menjadi relax saat menggunakan instagram akan dapat mengarah pada terjadinya perilaku adiksi instagram.

5. Tedapat perbedaan jenis kategori uses and gratification yang paling berpengaruh antara adiksi instagram feed dan adiksi instagram stories. Adiksi instagram feed lebih dipengaruhi oleh recognition needs sedangkan adiksi instagram stories lebih dipengaruhi oleh entertainment needs.

\section{Acknowledge}

Peneliti mengucapkan terima kasih kepada seluruh pihak yang telah turut serta membantu dan berkontribusi sehingga penelitian ini dapat dilaksankan dan diselesaikan tepat waktu.

\section{Daftar Pustaka}

[1] Abdulahi, A., Jalil, B., Lumpur, K., Samadi, M. B., \& Gharleghi, B. (2014). A Study on the Negative Effects of Social Networking Sites Such as Facebook among Asia Pacific University Scholars in Malaysia. International Journal of Business and Social Science.

[2] Alhabash, S., \& Ma, M. (2017). A Tale of Four Platforms: Motivations and Uses 
of Facebook, Twitter, Instagram, and Snapchat Among College Students? Social Media and Society. https://doi.org/10.1177/2056305117691544

[3] Arnett, J. J. (2014). Emerging adulthood: The winding road from the late teens through the twenties. New York, NY: Oxford University Press.

[4] Asosiasi Penyelanggara Jasa Internet Indonesia. (2020). Profil Pengguna Internet di Indonesia 2019. Jakarta.

[5] Atmoko, Bambang Dwi (2012). Instagram Handbook. In Jakarta: PT. TransMedia.

[6] Belanche, D., Cenjor, I., \& Pérez-Rueda, A. (2019). Instagram Stories versus Facebook Wall: an advertising effectiveness analysis. Spanish Journal of Marketing - ESIC, 23(1). https://doi.org/10.1108/SJME-09-2018-0042

[7] Floros, G. \& Siomos, K. (2013). The relationship between optimal parenting, Internet addiction and motives for social networking in adolescence. Psychiatry Research, 209, 529-534.

[8] Fox , J., \& Moreland, J. J. (2015). The dark side of social networking sites: An exploration of the relational and psychological stressors associated with Facebook use and affordances. Computers in Human Behavior. https://doi.org/10.1016/j.chb.2014.11.083

[9] Greenwood, D. N. (2013). Fame, Facebook, and Twitter: how attitudes about fame predict frequency and nature of social media use. Psychology of Popular Media Culture, 2, 222e236. http://dx.doi.org/10.1037/ppm0000013.

[10] Griffiths, M. (1995). Technological addictions. In Clinical psychology forum (pp. 14-14). Division of Clinical Psychology of the British Psychol Soc.

[11] Griffiths, M. (2005). A “components" model of addiction within a biopsychosocial framework. Journal of Substance Use. https://doi.org/10.1080/14659890500114359

[12] Griffiths, M. D., Kuss, D. J., \& Demetrovics, Z. (2014). Social Networking Addiction: An Overview of Preliminary Findings. In Behavioral Addictions: Criteria, Evidence,

[13] Gülnar, B., Balcý, S. \& Çakýr, V. (2010). Motivations of Facebook, You Tube and similar web sites users. Bilig, 54, 161-184

[14] Hootsuite, We Are Social, "Digital 2020. Indonesia," Hootsuite, United State, 2020. Diunduh melalui https://datareportal.com/reports/digital-2020-indonesia. pada 10 Desember 2020.

[15] Hwang, H. S., \& Cho, J. (2018). Why instagram? Intention to continue using instagram among Korean college students. Social Behavior and Personality. https://doi.org/10.2224/SBP.6961

[16] Instagram.com (2017, 29 November) About Instagram. Diakses melalui https://about.instagram.com/ pada 10 November 2020.

[17] Katz, E., Haas, H., \& Gurevitch, M. (1973). On the Use of the Mass Media for mportant Things. American Sociological Review. https://doi.org/10.2307/2094393

[18] Kircaburun, K., \& Griffiths, M. D. (2018). Instagram addiction and the Big Five of personality: The mediating role of self-liking. Journal of Behavioral Addictions, 7(1), 158-170.

[19] Krishnan, A., \& Hunt, D. S. (2015). Influence of a Multidimensional Measure of Attitudes on Motives to Use Social Networking Sites. Cyberpsychology, Behavior, and Social Networking. https://doi.org/10.1089/cyber.2014.0423

[20] Kuss, D. J., \& Griffiths, M. D. (2011). Online social networking and addiction- 
A review of the psychological literature. International Journal of Environmental Research and Public Health, 8(12), 3528-3552. .

[21] Kuss, D. J., \& Griffiths, M. D. (2017). Social networking sites and addiction: Ten lessons learned. International Journal of Environmental Research and Public Health, 14, 311.

[22] Mull, I. R. \& Lee, S. (2014). "PIN" pointing the motivational dimensions behind Pinterest. Computers in Human Behavior, 33, 192-200

[23] Safarina, N., \& Halimah, L. (2019, November). Self-control and online game addiction in early adult gamers. In Journal of Physics: Conference Series (Vol. 1375, No. 1, p. 012094). IOP Publishing.

[24] Napoleoncat.com. (2021). Instagram Users in Indonesia. Diakses melalui https://napoleoncat.com/stats/instagram-users-in-indonesia/2020/11 pada 20 Juni 2021.

[25] Ponnusamy, S., Iranmanesh, M., Foroughi, B., \& Hyun, S. S. (2020). Drivers and outcomes of Instagram Addiction: Psychological well-being as moderator. Computers in Human Behavior. https://doi.org/10.1016/j.chb.2020.106294

[26] Royal Society For Public Health. (2017). Instagram Ranked Worst for Young People's Mental Health. Diunduh melalui https://www.rsph.org.uk/aboutus/news/instagram-ranked-worst-for-young-people-s-mental-health.html pada 3 Januari 2021.

[27] Sheldon, P., \& Bryant, K. (2016). Instagram: Motives for its use and relationship to narcissism and contextual age. Computers in Human Behavior. https://doi.org/10.1016/j.chb.2015.12.059

[28] Sholeh, A., \& Rusdi, A. (2019). A New Measurement of Instagram Addiction: Psychometric Properties of The Instagram Addiction Scale (TIAS). CISAK.

[29] Siste, K., Hanafi, E., Sen, L. T., Christian, H., Adrian, Siswidiani, L. P., Limawan, A. P., Murtani, B. J., \& Suwartono, C. (2020). The Impact of Physical Distancing and Associated Factors Towards Internet Addiction Among Adults in Indonesia During COVID-19 Pandemic: A Nationwide Web-Based Study. Frontiers in Psychiatry. https://doi.org/10.3389/fpsyt.2020.580977

[30] Smock, A. D., Ellison, N. B., Lampe, C., \& Wohn, D. Y. (2011). Facebook as a toolkit: A uses and gratification approach to unbundling feature use. Computers in Human Behavior, 27(6). https://doi.org/10.1016/j.chb.2011.07.011

[31] Stockdale, L. A., \& Coyne, S. M. (2020). Bored and online: Reasons for using social media, problematic social networking site use, and behavioral outcomes across the transition from adolescence to emerging adulthood. Journal of Adolescence. https://doi.org/10.1016/j.adolescence.2020.01.010

[32] Tan, A. S. (1985). Mass communication: Theories and research (2nd ed.). New York, NY: Wiley

[33] The Center For Generational Kinetics (2016). Top 10 Gen $Z$ questions answered. Dikases melalui http://genhq.com/igen-gen-z-generation-z-centennials-info/ pada 20 April 2021

[34] Valkenburg, P. M., \& Peter, J. (2011). Online communication among adolescents: An integrated model of its attraction, opportunities, and risks. In Journal of Adolescent Health. https://doi.org/10.1016/j.jadohealth.2010.08.020

[35] Whiting, A., \& Williams, D. 2013. Why people use social media: a uses and gratifications approach. Qualitative Market Research: An International Journal, 16(4), 362e369.

[36] Wiederhold, B. K. (2019). Instagram: Becoming a worldwide problem? In 
Cyberpsychology, Behavior, and Social Networking. https://doi.org/10.1089/cyber.2019.29160.bkw

[37] Wu, J. H., Wang, S. C., \& Tsai, H. H. (2010). Falling in love with online games: The uses and gratifications perspective. Computers in Human Behavior. https://doi.org/10.1016/j.chb.2010.07.033 